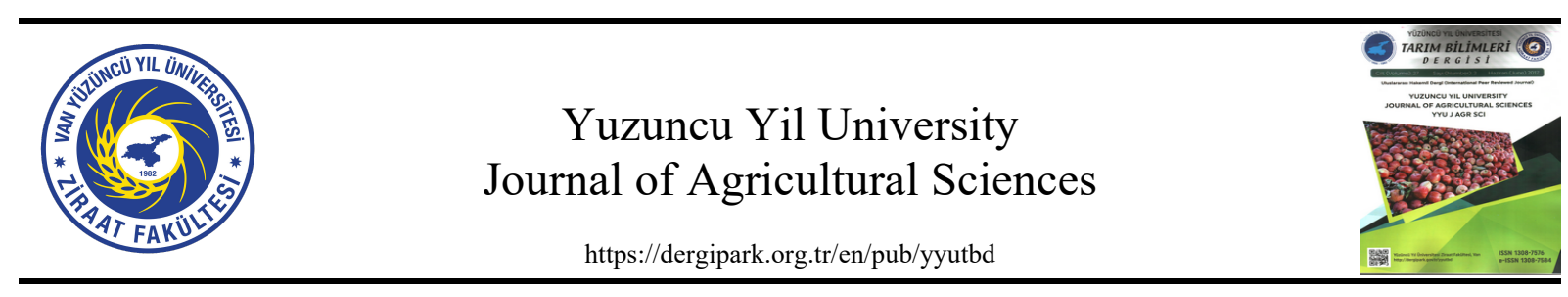

Araştırma Makalesi (Research Article)

\title{
Improvement of Grain Quality Traits in Bread Wheat Genotypes Through Mutation Breeding Using Gamma Irradiation
}

\author{
Alpay BALKAN"1 ${ }^{*}$ Ŏuz BÍLGİN ${ }^{2}$, İsmet BAȘER ${ }^{3}$ \\ 1,2,3 Tekirdağ Namık Kemal University, Faculty of Agriculture, Department of Field Crops, 5100 Tekirdağ, \\ Turkey
}

${ }^{1}$ https://orcid.org/0000-0002-9203-6144 ${ }^{2}$ https://orcid.org/0000-0002-4338-9912 ${ }^{3}$ https://orcid.org/0000-0001-6748-3750

*Corresponding author e-mail: abalkan@nku.edu.tr

\section{Article Info}

Received: 19.03.2021

Accepted: 07.12.2021

Online Published: 15.12 .2021

DOI: $10.29133 /$ yyutbd. 899862

Keywords

Gamma-ray,

Mutant population,

Quality,

Triticum aestivum $\mathrm{L}$.
Abstract: This study was conducted to determine changes for some quality characters in $\mathrm{M}_{2}, \mathrm{M}_{3}$ and $\mathrm{M}_{4}$ mutated populations of three bread wheat genotypes irradiated by different gamma rays. The results showed that the genotypes significantly and variably differed in their response for various traits at different gamma rays doses in $\mathrm{M}_{2}, \mathrm{M}_{3}$, and $\mathrm{M}_{4}$ populations. The shifts per see from the controls for examined quality characters such as thousand-grain weight (TGW), test weight (TW), wet gluten content (GC), gluten index (GI), Zeleny sedimentation value (ZSV), and protein content (PC) in mutant populations were significant according to t-test analysis. The results showed that desired variations could be obtained for quality traits in M2, M3, and M4 generations with different doses of gamma irradiation depending on bread wheat genotypes. Although the shifts per see from the controls for ZSV, GC, and PC were significant, TGW, GI, and TW showed an unchanged or slightly negative response in the $\mathrm{M}_{2}, \mathrm{M}_{3}$, and $\mathrm{M}_{4}$ generations. It can be generally said that it may be more appropriate to perform selection after $\mathrm{M}_{4}$ generation for seed quality traits in mutant populations. Although the effect of mutagen doses varies depending on the character, genotype, and mutagenesis generation examined, it can be said that the most appropriategammarayy doses are 300 and 200 Gy doses because of causing significant shifts per see from the controls.

\section{Ekmeklik Buğday Genotiplerinde Tane Kalitesi Özelliklerinin Gamma Işını Kullanılarak Mutasyon Islahı ile Geliştirilmesi}

\section{Makale Bilgileri}

Geliş: 19.03.2021

Kabul: 07.12.2021

Online Yayınlanma: 15.12.2021

DOI: 10.29133 /yyutbd.899862

Anahtar Kelimeler
Gamma 1şını,
Mutant popülasyon,
Kalite,
Triticum aestivum L.
Öz: Bu çalışma, farklı gamma 1şını ile ışınlanmış üç ekmeklik buğday genotipinin $\mathrm{M}_{2}, \mathrm{M}_{3}$ ve $\mathrm{M}_{4}$ mutant popülasyonlarında bazı kalite özelliklerindeki değişimin belirlenmesi için yürütülmüştür. Sonuçlar, $\mathrm{M}_{2}, \mathrm{M}_{3}$ ve $\mathrm{M}_{4}$ popülasyonlarında farklı gamma ışını dozlarında çeşitli özellikler için genotiplerin yanıtlarının önemli ve değişken bir şekilde farklı olduğunu göstermiştir. Mutant popülasyonlarında bin tane ağırlığı (BTA), hektolitre ağırlığı (HA), yaş glüten içeriği (YGI), glüten indeks (GI), Zeleny sedimantasyon değeri (ZSD) ve protein içeriği (PI) gibi kalite özelliklerinin kontrole göre değişimi t-testine göre önemli bulunmuştur. Sonuçlar, ekmeklik buğday genotiplerine bağlı olarak farklı dozlarda gamma ışını uygulaması ile M2, M3 ve M4 generasyonlarında kalite özellikleri için istenilen varyasyonların elde edilebileceğini göstermiştir. $\mathrm{M}_{2}, \mathrm{M}_{3}$ ve $\mathrm{M}_{4}$ generasyonlarında kontrollere göre ZSD, YGİ ve Pİ de önemli değişimler olmasında rağmen, BTA, Gİ ve HA da ise değişim olmamış ya da biraz olumsuz bir değişim olmuştur. 
Genel olarak, mutant popülasyonlarda tane kalitesi özellikleri için $\mathrm{M}_{4}$ generasyonundan seleksiyon yapmanın daha uygun olabileceği söylenebilir. Mutagen dozlarının etkisi incelenen özelliğe, genotipe ve mutant generasyona bağlı olarak değişmekle birlikte, kontrollere göre önemli değişimlere neden olduğundan dolayı 200 ve 300 Gy dozlarının en uygun gamma ışını dozları olduğu söylenebilir.

\section{Introduction}

The main goal in wheat breeding is to develop high-yielding varieties with functional characteristics acceptable to producers, processors, and consumers. This means a success that cannot be underestimated because producers strive for high efficiency, processors need highly functional flour, and consumers demand and expect excellent sensory qualities in final products (Seabourn et al., 2012). Bread wheat flour is a functional flour that is mainly used in making bread, cookies, and pastries (Brankovic et al., 2018). Hence, both the milling and bakery industries require varieties with highquality flour to produce appropriate flour and finished products. As good quality wheat can be sold at high prices, there is a high demand among farmers for varieties with good baking and milling quality (Byerlee and Moya, 1993). Generally, the best way to determine the wheat quality, which is defined as industrial use, cooking quality, and the quality of the final product, is to evaluate its technological traits. Therefore, it is tried to decide its rheological or technological quality by examining the properties of wheat flour such as protein content, sediment volume, loaf volume, hardness, wet gluten, gluten index. The best way for determining the quality of bread wheat is primarily the evaluation of grain physicochemical properties for its use in industry, cooking quality, and appropriateness of the quality of the final product. That's the reason why determining thousand grain weight, test weight, wet gluten content, gluten index, Zeleny sedimentation value, protein content, and understanding of its rheological features are important (Ahmadi-Gavligi et al., 2004).

Mutagenesis and hybridization are generally the most commonly preferred breeding methods for the development of new superior commercial varieties. Since the mutagen-derived variability for quantitative traits in crop plants is inherited, and the selection response gives good results, many breeders believe that induced mutations can be used to generate beneficial variation in quantitatively inherited traits where appropriate selection for genetic improvement is applied (MacKay, 2011; Mba, 2013). It causes widespread changes in the morphological, physiological, and quality characteristics after the application of the mutagenic agent.It has been reported that the yield can be increased with the induced mutation, as well as other agronomic characters such as stiffness of straw, time of maturity, adaptability, shattering resistance, disease resistance, protein content, baking quality, malting quality and numerous other characters (Brunner, 1991). In recent years, the application of induced mutation in the improvement of several superior crop varieties has been at the forefront in many countries (developed countries being a priority), and this has had a greater economic impact on food production and nourishment of humanity (Kharkwal and Shu, 2009). The leading countries are China, India, the former USSR, the Netherlands, Japan, and the USA, with the highest number of mutant varieties officially released. Among the mutagens, the highest percentage (>50\%) was gamma rays used in the development of mutant varieties. Crop wise, the number of mutants developed was highest in grains, followed by ornamentals, legumes, and other crops, including legumes and vegetables, forage crops, edible oil crops, and tree species (Mba et al., 2010). Of all crops, rice was the crop with the highest number of mutants (700 mutant varieties), followed by barley, common wheat, corn, durum wheat, oats, millet, sorghum, and rye. According to the FAO / IAEA database, 1,825 mutants (corresponding to 57\%) were registered for both agronomic and botanical characteristics; of these, 577 mutants (18\%), 321 mutants (10\%), 200 mutants $(6 \%)$, and 125 mutants $(4 \%)$ were distinguished by increased yield and related traits, better quality and nutrient content, biotic stress tolerance, and abiotic stress tolerance respectively (Suprasanna et al., 2015). Although these mutant varieties have created a greater economic impact by contributing millions of dollars to local economies annually (Ahloowalia et al., 2004; Jain, 2005), unfortunately, the mutant wheat varieties that are expected to provide this extraordinary effect have not yet been developed in our country.

In addition to its protective role from insects and microorganisms and its sterilization effect, it is known that gamma irradiation has important effects on various quality criteria of cereal grains. There 
are many studies to examine the effects of gamma irradiation on wheat technological quality, such as grinding, dough, and baking quality characteristics (Paredes-Lopez and Covarrubias-Alvarez, 1984). Many studies have been fulfilled on improving wheat quality through gamma irradiation to extend the shelf life of whole-wheat flour (Marathe et al., 2002) and to increase the activity of endogenous amylases of wheat (Gralik and Warchalewski, 2006). There are also several studies to elucidate the effect of gamma irradiation treatments on gluten protein and gluten fractions (Nayeem et al., 1999).

This paper concentrated to determine the effects of different gamma rays doses on some quality traits of mutant genotypes. The knowledge obtained through this research will be helpful for the breeders while making a selection of potentially improved wheat mutant germplasm.

\section{Materials and Methods}

A total of 3 bread wheat genotypes (Bezostaja 1, IBWSN4, and Kate A1) were chosen to represent likely diversity in earliness, disease resistance, awn type of spike, plant height, and flour quality.

The experiments were set up with 15 irradiated seeds combination along with the un-irradiated (control) in the experimental field of the Field Crops Department of the Faculty of Agriculture of Tekirdağ Namık Kemal University during consecutive growing seasons of 2011-2012, 2012-2013, and 2013-2014 with four replicated. It was made following the required agronomic and cultural practices method. Nitrogen and $\mathrm{P}_{2} 0_{5}$ at 160 and $50 \mathrm{~kg} \mathrm{ha}^{-1}$, respectively, were incorporated into the soil as compound fertilizer (20-20-0) before sowing, urea during tillering, and ammonium nitrate before the heading stage. The crop was kept free of weeds by hand hoeing as necessary.

Some quality traits such as thousand kernel weight (TKW), test weight (TW), protein content (PC), wet gluten content (WGC), gluten index (GI), and Zeleny sedimentation value (ZSV) (for methods see Balkan, 2018) were evaluated in mutated populations of $\mathrm{M}_{2}, \mathrm{M}_{3}$, and $\mathrm{M}_{4}$.

The data thus collected on mentioned above quality traits were subjected to analysis of statistical manipulation as outlined by Steel and Torrie (1980). The statistical analysis was concerned mainly as a comparison between data of the control and that of the corresponding population using two groups t-test (means) and one tail F-ratio (variances).

\section{Results and Discussion}

The significances of mean squares (MS) from pooled ANOVA through the ' $\mathrm{F}$ ' test for TGW, TW, GC, GI, ZSV, and PC traits in bread wheat mutated populations of $\mathrm{M}_{2}, \mathrm{M}_{3}$ and $\mathrm{M}_{4}$ were given in Table 1.

Table 1. Results of variance analyses for quality traits in bread wheat mutated populations of $\mathrm{M}_{2}, \mathrm{M}_{3}$, and $\mathrm{M}_{4}$

\begin{tabular}{|c|c|c|c|c|c|c|c|c|c|c|c|c|}
\hline \multirow[b]{2}{*}{ Characters } & \multicolumn{3}{|c|}{$\begin{array}{c}\text { Replication } \\
\text { d.f. }=2\end{array}$} & \multicolumn{3}{|c|}{$\begin{array}{c}\text { Treatments } \\
\text { d.f. }=5\end{array}$} & \multicolumn{3}{|c|}{$\begin{array}{c}\text { Genotype } \\
\text { d.f. }=2\end{array}$} & \multicolumn{3}{|c|}{$\begin{array}{l}\text { Treatment } \mathrm{x} \\
\text { genotype int. } \\
\text { d.f. }=10\end{array}$} \\
\hline & $\mathrm{M}_{2}$ & $\mathrm{M}_{3}$ & $\mathrm{M}_{4}$ & $\mathrm{M}_{2}$ & $\mathrm{M}_{3}$ & $\mathrm{M}_{4}$ & $\mathrm{M}_{2}$ & $\mathrm{M}_{3}$ & $\mathrm{M}_{4}$ & $\mathrm{M}_{2}$ & $\mathrm{M}_{3}$ & $\mathrm{M}_{4}$ \\
\hline TGW (g) & $*$ & ns & ns & $*$ & $* *$ & $*$ & $* *$ & $* *$ & $* *$ & $* *$ & $*$ & $* *$ \\
\hline $\mathrm{TW}(\mathrm{kg} / \mathrm{hl})$ & ns & ns & $*$ & $* *$ & $* *$ & $* *$ & $* *$ & $* *$ & $* *$ & $\mathrm{~ns}$ & $\mathrm{~ns}$ & $* *$ \\
\hline $\mathrm{GC}(\%)$ & $* *$ & ns & ns & $* *$ & $* *$ & $*$ & $* *$ & ns & $* *$ & $* *$ & $* *$ & $* *$ \\
\hline GI & ns & ns & ns & $*$ & ns & ns & $* *$ & $* *$ & $* *$ & $*$ & $*$ & $* *$ \\
\hline ZSV (ml) & $*$ & ns & $*$ & $* *$ & $* *$ & $\mathrm{~ns}$ & $* *$ & $* *$ & $* *$ & ns & $*$ & ns \\
\hline $\mathrm{PC}(\%)$ & $* *$ & ns & ns & $* *$ & $* *$ & $* *$ & $* *$ & $* *$ & $* *$ & ns & ns & $*$ \\
\hline
\end{tabular}

d.f.: degree of freedom, ns: non-significant, *: significance at $5 \%$ level, **: significance at $1 \%$ level.

The ' $F$ ' test indicated that variances due to genotypes were highly significant for all the characters except $\mathrm{GC}$ in $\mathrm{M}_{3}$, which provided evidence for the significant genetic variability for the traits among the varieties. The results of variance analysis for the treatments (which means the gamma 
radiation doses) indicated that the traits out of $\mathrm{GI}$ in the $\mathrm{M}_{3}$ and $\mathrm{M}_{4}, \mathrm{ZSV}$ in the $\mathrm{M}_{4}$ under study were highly significant at $(\mathrm{p}<0.01)$ probability level. Mean values in 100, 200, 300, 400, and 500 Gy of gamma rays and its controls for the investigated characters in the $\mathrm{M}_{2}, \mathrm{M}_{3}$, and $\mathrm{M}_{4}$ mutated populations of three bread genotypes were presented in Tables 2-4, and following results explore the findings of the present investigation.

In the present study, it is seen that there were significant increases in some characters in terms of quality traits in $\mathrm{M}_{2}, \mathrm{M}_{3}$ and $\mathrm{M}_{4}$ mutated populations of Bezostaja 1 variety (Table 2).

Table 2. Variation of some quality properties according to standards (non-mutants) in the mutant progeny of in $\mathrm{M}_{2}, \mathrm{M}_{3}$, and $\mathrm{M}_{4}$ generation of Bezostoja 1 variety

\begin{tabular}{|c|c|c|c|c|c|c|c|c|c|c|c|c|c|}
\hline \multirow{2}{*}{\multicolumn{2}{|c|}{$\begin{array}{c}\text { Gamma } \\
\text { doses } \\
(\mathrm{Gy})\end{array}$}} & \multicolumn{2}{|c|}{ TGW (g) } & \multicolumn{2}{|c|}{ TW $\left(\mathrm{kghl}^{-1}\right)$} & \multicolumn{2}{|c|}{ WGC (\%) } & \multicolumn{2}{|l|}{ GI } & \multicolumn{2}{|c|}{ ZSV (ml) } & \multicolumn{2}{|c|}{$\mathrm{PC}(\%)$} \\
\hline & & $\begin{array}{c}\text { Mean } \pm \text { SE } \\
(\mathrm{g})\end{array}$ & $\begin{array}{l}\text { Shift } \\
(\%)\end{array}$ & $\begin{array}{l}\mathrm{Mean} \pm \mathrm{SE} \\
\left(\mathrm{kghl}^{-1}\right)\end{array}$ & $\begin{array}{l}\text { Shift } \\
(\%)\end{array}$ & $\begin{array}{l}\text { Mean } \pm \text { SE } \\
(\%)\end{array}$ & $\begin{array}{l}\text { Shift } \\
(\%)\end{array}$ & $\begin{array}{l}\text { Mean } \pm \text { SE } \\
(\%)\end{array}$ & $\begin{array}{l}\text { Shift } \\
(\%)\end{array}$ & $\begin{array}{l}\text { Mean } \pm \text { SE } \\
(\mathrm{ml})\end{array}$ & $\begin{array}{l}\text { Shift } \\
(\%)\end{array}$ & $\begin{array}{c}\text { Mean } \pm \text { SE } \\
(\%)\end{array}$ & $\begin{array}{l}\text { Shift } \\
(\%)\end{array}$ \\
\hline \multirow{6}{*}{$\mathrm{M}_{2}$} & Cont. & $37.8 \pm 0.17$ & 0.0 & $74.3 \pm 1.04$ & 0.0 & $24.2 \pm 0.39$ & 0.0 & $87.7 \pm 0.33$ & 0.0 & $40.9 \pm 1.17$ & 0.0 & $11.87 \pm 0.18$ & 0.0 \\
\hline & 100 & $37.6 \pm 0.78$ & -0.5 & $76.4 \pm 0.09 *$ & 2.8 & $21.8 \pm 0.34 * *$ & -9.9 & $87.7 \pm 0.67$ & 0.0 & $40.3 \pm 0.78$ & -1.5 & $11.70 \pm 0.23$ & -1.4 \\
\hline & 200 & $36.2 \pm 0.76^{* *}$ & -4.2 & $72.9 \pm 0.77$ & -1.9 & $23.5 \pm 0.47$ & -2.9 & $86.3 \pm 0.33 *$ & -1.6 & $41.7 \pm 0.35$ & 2.0 & $11.73 \pm 0.23$ & -1.2 \\
\hline & 300 & $35.3 \pm 1.13^{* *}$ & -6.6 & $76.9 \pm 0.96 *$ & 3.5 & $24.2 \pm 0.73$ & 0.0 & $88.7 \pm 0.33$ & 1.1 & $44.2 \pm 1.15^{* *}$ & 8.1 & $10.90 \pm 0.17 *$ & -8.2 \\
\hline & 400 & $38.6 \pm 0.47$ & 2.1 & $75.3 \pm 1.11$ & 1.4 & $25.0 \pm 0.43$ & 3.3 & $90.3 \pm 0.33 * *$ & 3.0 & & 5.1 & $11.87 \pm 0.52$ & 0.0 \\
\hline & 500 & $38.3 \pm 1.37$ & 1.3 & $72.6 \pm 0.45$ & -2.3 & $27.5 \pm 0.87^{* *}$ & 13.6 & $89.7 \pm 1.20^{*}$ & 2.3 & $47.1 \pm 0.96^{* *}$ & 15.2 & $12.57 \pm 0.75^{*}$ & 5.9 \\
\hline \multirow{6}{*}{$\mathrm{M}_{3}$} & Cont. & $35.6 \pm 0.45$ & 0.0 & $77.3 \pm 0$. & 0.0 & $36.3 \pm 0.18$ & 0.0 & $78.3 \pm 1.67$ & 0.0 & $52.0 \pm 1.53$ & 0.0 & $14.37 \pm 0.13$ & 0.0 \\
\hline & 100 & $35.6 \pm 0.65$ & 0.0 & $77.1 \pm 0$ & -0.3 & $35.0 \pm 1.08^{*}$ & -3.6 & $79.3 \pm 0.67$ & 1.3 & $52.7 \pm 1$ & 1.41 & $14.33 \pm 0.32$ & -0.3 \\
\hline & 200 & $32.7 \pm 0.56^{* *}$ & -8.2 & $77.3 \pm 0.09$ & 0.0 & $37.0 \pm 0.48$ & 1.9 & $75.0 \pm 1.89 *$ & -4.2 & $50.7 \pm 1$ & -2.51 & $14.50 \pm 0.06$ & 0.9 \\
\hline & 300 & $31.9 \pm 0.56^{* *}$ & -10.4 & $76.5 \pm 0$ & -1.0 & $36.0 \pm 0.12$ & -0.8 & $83.3 \pm 1.67^{* *}$ & 6.4 & $53.7 \pm 0.88$ & 3.31 & $14.60 \pm 0.15^{*}$ & 1.6 \\
\hline & 400 & $32.4 \pm 0.10^{* *}$ & -9.0 & $76.9 \pm 0.13$ & -0.5 & $35.8 \pm 0.55^{*}$ & -1.4 & $78.3 \pm 1.67$ & 0.0 & $52.7 \pm 1.86$ & 1.4 & $14.30 \pm 0.25$ & -0.5 \\
\hline & 500 & $31.8 \pm 0.63 * *$ & -10.7 & $76.3 \pm 0$ & -1.3 & $37.0 \pm 0.87$ & 1.9 & $76.0 \pm 1.06$ & -2.9 & $53.3 \pm 1.20$ & 2.51 & $14.33 \pm 0.23$ & -0.3 \\
\hline \multirow{6}{*}{$\mathrm{M}_{4}$} & Cont. & $44.6 \pm 0.55$ & 0.0 & $81.3 \pm$ & 0.0 & $44.5 \pm 2.00$ & 0.0 & $61.7 \pm 1.67$ & 0.0 & $49.3 \pm 1.33$ & 0.01 & $14.40 \pm 0.15$ & 0.0 \\
\hline & 100 & $47.0 \pm 0.69 *$ & 5.4 & $81.9 \pm 0.23$ & 0.7 & $43.6 \pm 0.76$ & -2.0 & $75.0 \pm 1.16^{* *}$ & 21.6 & $56.7 \pm 1.20 * *$ & 15.0 & $14.77 \pm 0.15$ & 2.6 \\
\hline & 200 & $48.1 \pm 0.58 * *$ & 7.9 & $83.1 \pm 0.24 *$ & 2.2 & $42.9 \pm 1.11$ & -3.6 & $71.7 \pm 1.67 * *$ & 16.2 & $57.3 \pm 1.20 * *$ & 16.2 & $14.73 \pm 0.23$ & 2.3 \\
\hline & 300 & $47.8 \pm 0.71 *$ & 7.2 & $82.9 \pm 0.44^{*}$ & 2.0 & $43.5 \pm 0.58$ & -2.3 & $73.3 \pm 1.67 * *$ & 18.8 & $59.0 \pm 1.00 * *$ & 19.7 & $14.90 \pm 0.10$ & 3.5 \\
\hline & 400 & $45.9 \pm 0.30 *$ & 2.9 & $82.3 \pm 0.52$ & 1.2 & $44.8 \pm 0.79$ & 0.7 & $68.3 \pm 1.67^{* *}$ & 10.7 & $53.7 \pm 0.88 * *$ & 8.9 & $15.20 \pm 0.20 * *$ & 5.6 \\
\hline & 500 & $44.1 \pm 0.30$ & -1.1 & $81.5 \pm 0.31$ & 0.3 & $45.1 \pm 0.90$ & 1.4 & $72.7 \pm 1.33^{* *}$ & 17.8 & $57.3 \pm 0.67 * *$ & 16.21 & $15.07 \pm 0.03 * *$ & 4.7 \\
\hline
\end{tabular}

SE: Standard error, Cont.: Control, * and ${ }^{*}$ statistically significant differences from control at $5 \%$ and $1 \%$.

In the $\mathrm{M}_{2}$ mutated population of Bezostoja 1 variety, there was a gradual statistically increase for TW at values of 2.8 and $3.5 \%$ in 100 and $300 \mathrm{~Gy}$, GI at values of 2.3 and $3.0 \%$ in 500 and $400 \mathrm{~Gy}$, ZSV at values 5.1, 8.1 and $15.2 \%$ in 400, 300 and $500 \mathrm{~Gy}$ and $\mathrm{PC}$ at the value of $5.9 \%$ in $500 \mathrm{~Gy}$ respectively, compared to controls. On the other hand, there were statistically significant decreases in the mutant populations for TGW in 200 and $300 \mathrm{~Gy}$, WGC in $100 \mathrm{~Gy}$, GI in $200 \mathrm{~Gy}$, and PC in $300 \mathrm{~Gy}$ of the same generation.

Regarding the $\mathrm{M}_{3}$ mutated population of Bezostoja 1 variety, significant positive shifts in quantitative mean performance were observed for GI with the value of $6.4 \%$ in $300 \mathrm{~Gy}$ and PC with the value of $1.6 \%$ in $300 \mathrm{~Gy}$. However, in the $\mathrm{M}_{3}$ generation, statistically significant decreases were achieved in the mutant populations for TGW in 500, 300, 400, and 200 Gy and WGC in 100 and 400 Gy, compared to controls.

In the $\mathrm{M}_{4}$ generation, there weee a gradual increase for TGW, GI, ZSV, and PC traits characters while comparing to $\mathrm{M}_{2}$ and $\mathrm{M}_{3}$ generations of Bezostaja 1 variety. Among the $\mathrm{M}_{4}$ mutated populations, remarkable increases than control were provided for TGW with values of 7.9, 7.2, 5.4, and $2.9 \%$ in 200, 300,100 , and $400 \mathrm{~Gy}$, TW with values of 2.0 and $2.2 \%$ in 200 and $300 \mathrm{~Gy}$, GI with values of 21.6, $18.8,17.8,16.2$ and $10.7 \%$ in $100,300,500,200$ and $400 \mathrm{~Gy}, \mathrm{ZSV}$ with values of 19.7, 16.2, 15.0 and $8.9 \%$ in $300,200,500,100$ and $400 \mathrm{~Gy}, \mathrm{PC}$ with values of 5.6 and $4.7 \%$ in 400 and $500 \mathrm{~Gy}$, while a significant negative shift in quality mean performances was not observed for Bezostaja 1 variety.

Under the effect of gamma mutagenesis in the progeny $\left(\mathrm{M}_{2}-\mathrm{M}_{4}\right)$ of IBWSN4 advanced line, significant differences in variability of many traits of seed quality were observed (Table 3 ). 
Table 3. Variation of some quality properties according to standards (non-mutants) in the mutant progeny of in $\mathrm{M}_{2}, \mathrm{M}_{3}$, and $\mathrm{M}_{4}$ generation of IBWSN4 genotype

\begin{tabular}{|c|c|c|c|c|c|c|c|c|c|c|c|c|}
\hline \multirow{2}{*}{\multicolumn{2}{|c|}{$\begin{array}{c}\text { Gamma } \\
\text { doses } \\
\text { (Gy) }\end{array}$}} & \multicolumn{2}{|l|}{ TGW (g) } & \multicolumn{2}{|c|}{ TW (kg/hl) } & \multicolumn{2}{|c|}{ WGC (\%) } & \multicolumn{2}{|l|}{ GI } & $\mathrm{ZSV}(\mathrm{ml})$ & \multicolumn{2}{|l|}{$\mathrm{PC}(\%)$} \\
\hline & & $\begin{array}{c}\text { Mean } \pm \text { SE } \\
(\mathrm{g})\end{array}$ & $\begin{array}{r}\text { Shift } \\
(\%)\end{array}$ & $\begin{array}{c}\text { Mean } \pm \text { SE } \\
\left(\mathrm{kghh}^{-1}\right)\end{array}$ & $\begin{array}{r}\text { Shift } \\
(\%)\end{array}$ & $\begin{array}{l}\text { Mean } \pm \text { SE } \\
(\%)\end{array}$ & $\begin{array}{l}\text { Shift } \\
(\%)\end{array}$ & $\begin{array}{c}\text { Mean } \pm \text { SE } \\
(\%)\end{array}$ & $\begin{array}{c}\text { Shift } \\
(\%)\end{array}$ & $\begin{array}{c}\text { Mean } \pm \text { SE } \\
(\mathrm{ml})\end{array}$ & $\begin{array}{cc}\text { Shift } & \text { Mean } \pm \text { SE } \\
(\%) & (\%)\end{array}$ & $\begin{array}{l}\text { Shift } \\
(\%)\end{array}$ \\
\hline \multirow{6}{*}{$\mathrm{M}_{2}$} & Cont. & $33.4 \pm 0.54$ & 0.0 & $70.7 \pm 0.59$ & 0.0 & $21.6 \pm 0.15$ & 0.0 & $80.7 \pm 0.88$ & 0.0 & $32.6 \pm 1.06$ & $0.011 .00 \pm 0.12$ & 0.0 \\
\hline & 100 & $36.4 \pm 0.69 *$ & 9.0 & $73.7 \pm 0$. & 4.2 & $23.2 \pm 0.64 * *$ & 7.4 & & -3.0 & & $-0.310 .90 \pm 0.55$ & -0.9 \\
\hline & 200 & $36.6 \pm 0.40^{* *}$ & 9.6 & $70.6 \pm($ & -0.1 & $23.3 \pm 0.9$ & 7.9 & $80.7 \pm 0$ & 0.03 & & $2.810 .27 \pm 0.09^{* *}$ & $*-6.6$ \\
\hline & 300 & $36.5 \pm 1.23^{*}$ & 9.3 & $71.0 \pm 1$ & 0.4 & $24.3 \pm 0.38 * *$ & 12.5 & $82.7 \pm 0.88 *$ & 2.5 & $33.8 \pm 1.67 *$ & $3.710 .50 \pm 0.15^{*}$ & -4.6 \\
\hline & 400 & $37.4 \pm 0.9$ & 12.0 & 71.0 & 0.4 & $20.0 \pm 1$ & -7.4 & $83.0 \pm 0.58 *$ & $2.9 ?$ & $0^{*}$ & $3.710 .17 \pm$ & $*-7.6$ \\
\hline & 500 & $38.0=$ & 13.8 & 69. & -1.4 & 23.0 & 6.5 & $78.0 \pm 0.58 * *$ & -3.4 & & 9.211 & 2.7 \\
\hline \multirow{6}{*}{$\mathrm{M}_{3}$} & Cont. & & 0.0 & $74.8 \pm$ & 0.0 & & 0.0 & & 0.0 & & & 0.0 \\
\hline & 100 & $29.3 \pm 0.48 * *$ & -6.7 & 74.9 & 0.1 & & 0.3 & $58.3 \pm 0.88 * *$ & -18.7 & & $.12 *$ & 2.6 \\
\hline & 200 & $28.6 \pm 0.46^{* *}$ & -8.9 & $74.3 \pm 0$ & -0.7 & $33.1 \pm 0.8$ & -3.2 & $66.7 \pm 0.67 * *$ & -7.0 & $37.3 \pm 0.33$ & $-1.113 .23 \pm 0.18^{*}$ & 2.6 \\
\hline & 300 & $28.8 \pm 0.40$ & -8.3 & $72.2 \pm 1$ & -3.5 & $36.6 \pm 0.87 * *$ & 7.0 & $67.7 \pm 0.88 * *$ & -5.6 & $37.7 \pm 0.8$ & $0.013 .33 \pm 0.18^{* *}$ & $* 3.3$ \\
\hline & 400 & $27.3 \pm$ & -13.1 & $72.5 \pm$ & -3.1 & $70^{* *}$ & 4.4 & 67 & 2.2 & $5.7 \pm 0.88 * * 2$ & $21.213 .77 \pm 0.03 * *$ & * 6.7 \\
\hline & 500 & $28.7 \pm 0.51 * *$ & -8.6 & $71.9 \pm 0$ & -3.9 & $39.0 \pm 0$ & 14.0 & 20 & 0.0 & $58 * *$ & $19.413 .53=$ & $* 4.9$ \\
\hline \multirow{6}{*}{$\mathrm{M}_{4}$} & Cont. & $43.0 \pm 0.31$ & 0.0 & $78.1 \pm$ & 0.0 & $37.2 \pm 0.88$ & 0.0 & $66.7 \pm 0.88$ & 0.0 & 37.0 & 0.013 .33 & 0.0 \\
\hline & & & 1.9 & 79.2 & 1.4 & $46.1 \pm 1.33^{* *}$ & 23.9 & $53.3 \pm 1.33 * *$ & -20.1 & $8 * *$ & $8.914 .20 \pm 0.12 * *$ & * 6.5 \\
\hline & 200 & $43.8 \pm 0.60$ & 1.9 & $79.2 \pm 0$ & 1.4 & $42.3 \pm 0.33 * *$ & 13.7 & $61.7 \pm 0.33 *$ & -7.5 & $38.7 \pm 0.67$ & $4.614 .10 \pm 0.17 * *$ & * 5.8 \\
\hline & 300 & & 1.2 & $81.3 \pm 0$. & 4.1 & & 23.1 & $57.7 \pm 1.45^{* *}$ & -13.5 & $40.3 \pm 0.33^{* *}$ & $8.914 .47 \pm 0.09 * *$ & 8.6 \\
\hline & 400 & $43.1 \pm$ & 0.2 & $81.6 \pm 0.12 * *$ & 4.5 & $39.9 \pm 1.15^{* *}$ & 7.3 & $60.0 \pm 1.15^{* *}$ & -10.13 & $35.7 \pm 0.33$ & $-3.513 .80 \pm 0.15$ & 3.5 \\
\hline & 500 & $44.0 \pm 0.32$ & 2.3 & $80.0 \pm 0.26^{* *}$ & 2.4 & $42.4 \pm 0.67 * *$ & 14.0 & $61.7 \pm 0.67^{*}$ & -7.5 & $41.7 \pm 0.67 * *$ & $12.714 .13 \pm 0.03 * *$ & $* 6.0$ \\
\hline
\end{tabular}

SE: Standard error, Cont.: Control, * and ** statistically significant differences from control at $5 \%$ and $1 \%$.

In the $\mathrm{M}_{2}$ mutated population of the advanced lines, there was a gradual statistically increase for TGW at values of $13.8,12.0,9.6,9.3$, and $9.0 \%$ in 500, 400, 200, 300, and $100 \mathrm{~Gy}$, TW at the value of $4.2 \%$ in $100 \mathrm{~Gy}$, WGC at values of $12.5,7.9,7.4$ and $6.5 \%$ in $300,200,100$ and $500 \mathrm{~Gy}$, GI at values of 2.9 and $2.5 \%$ in 400 and $300 \mathrm{~Gy}$ and ZSV at values of 9.2, 3.7 and 3.7\% in 500, 300 and $400 \mathrm{~Gy}$ respectively, compared to controls. On the other hand, there were statistically significant decreases in the mutant populations for GI in 500 and $100 \mathrm{~Gy}$ and PC in 400, 200, and $300 \mathrm{~Gy}$ of the mutated population.

In the case of the mutated IBWSN4 $\mathrm{M}_{3}$ population, a significant positive shift in quantitative mean performance was observed in WGC at the values 14.0, 7.0, and 4.4\% (500, 300, and $400 \mathrm{~Gy})$, ZSV at the values of 21.2 and 19.4 (500 and $400 \mathrm{~Gy}$ ), and $\mathrm{PC}$ at the values of 6.7, 4.9, 3.3, 2.6 and 2.6\% $(400,500,300,200$ and $100 \mathrm{~Gy})$, while the significant reductions were observed for TGW at 400, 200, 500,300 and 100 Gy (13.1, 8.9, 8.6, 8.3 and 6.7\%), TW at 500, 300 and 400 Gy (3.9, 3.5 and 3.1\%), WGC at $200 \mathrm{~Gy}(3.2 \%)$ and GI at 100, 200 and $300 \mathrm{~Gy}(18.7,7.0$ and 5.6\%) of gamma rays.

Regarding the $\mathrm{M}_{4}$ mutated population of IBWSN4 advanced line, significant positive shifts in quantitative mean performance were observed for TW with values of 4.5, 4.1 and 2.4\% in 400,300, and $500 \mathrm{~Gy}$, WGC with values of 23.9, 23.1, 14.0, 13.7, and 7.0\% in 100, 300, 500, 200 and $400 \mathrm{~Gy}, \mathrm{ZSV}$ with values of $12.7,8.9$ and $8.9 \%$ in 500, 300 and $100 \mathrm{~Gy}$ and $\mathrm{PC}$ with values of 8.6, 6.5, 6.0 and 5.8\% in 300, 100, 500 and $200 \mathrm{~Gy}$. However, statistically, significant decreases were achieved in the mutant populations of the advanced line for GI in 100, 300, 400, 500, and $200 \mathrm{~Gy}$, compared to controls.

It is understood from the comparison of the mean values of the mutated population of Kate A1 bread wheat variety and their control averages that the data obtained in the $\mathrm{M}_{2}, \mathrm{M}_{3}$, and $\mathrm{M}_{4}$ generations showed significant increases in some quality traits (Table 4).

In the $\mathrm{M}_{2}$ mutated population of Kate A-I variety, there was a gradual statistically increase for TW at the value of $3.1 \%$ in $100 \mathrm{~Gy}$, WGC at the value of $5.6 \%$ in $500 \mathrm{~Gy}$, GI at values of 5.7, 4.6, 4.2, 3.9 and $3.4 \%$ in 500, 200, 400, 300 and 100 Gy and ZSV at value $8.6 \%$ in 500 Gy respectively, compared to controls. On the other hand, there were statistically significant decreases in the mutant populations for WGC in $200 \mathrm{~Gy}(6.4 \%)$ and ZSV in 200 and $300 \mathrm{~Gy}(11.8$ and $9.9 \%)$.

In the case of mutated IBWSN4 $\mathrm{M}_{3}$ population, a significant positive shift in quantitative mean performance was observed in WGC at the values 8.5, 7.1, and 3.7\% (300, 400, and $500 \mathrm{~Gy})$, WGC at the values of 8.5, 7.1, and $3.7 \%(300,400$ and $500 \mathrm{~Gy})$, GI at the values of $7.7 \%$ (100 and $400 \mathrm{~Gy})$, ZSV at the values of 23.5, 13.1 and $9.7 \%(500,300$ and $400 \mathrm{~Gy})$ and $\mathrm{PC}$ at the values of 6.5, 5.9 and $5.4 \%$ (400, 300 and $500 \mathrm{~Gy}$ ), while the significant reductions were observed for TGW at 400, 100, 500, 
and 200 Gy (10.7, 6.2, 5.5 and 4.6\%), TW at 400, 500, 300, 200 and 100 Gy (3.7, 3.0, 2.4, 2.4 and $1.0 \%)$, WGC at $100 \mathrm{~Gy}(4.0 \%)$, GI at 200, 300 and $500 \mathrm{~Gy}(7.7 \%), \mathrm{ZSV}$ at 200 and $100 \mathrm{~Gy}$ (8.6 and $6.0 \%)$ and $\mathrm{PC}$ at $100 \mathrm{~Gy}(1.8 \%)$ of gamma rays.

Table 4. Variation of some quality properties according to standards (non-mutants) in the mutant progeny of in $\mathrm{M}_{2}, \mathrm{M}_{3}$, and $\mathrm{M}_{4}$ generation of Kate A1 variety

\begin{tabular}{|c|c|c|c|c|c|c|c|c|c|c|c|}
\hline & \multirow{2}{*}{$\begin{array}{c}\text { Gamma } \\
\text { doses } \\
\text { (Gy) }\end{array}$} & \multicolumn{2}{|c|}{ TGW (g) } & \multicolumn{2}{|c|}{ TW $\left(\mathrm{kghl}^{-1}\right)$} & \multicolumn{2}{|c|}{ WGC (\%) } & GI & ZSV (ml) & \multicolumn{2}{|l|}{$\mathrm{PC}(\%)$} \\
\hline & & $\begin{array}{l}\text { Mean } \pm \text { SE } \\
(\mathrm{g})\end{array}$ & $\begin{array}{l}\text { Shift } \\
(\%)\end{array}$ & $\begin{array}{l}\text { Mean } \pm \text { SE } \\
\left(\mathrm{kghl}^{-1}\right)\end{array}$ & $\begin{array}{l}\text { Shift } \\
(\%)\end{array}$ & $\begin{array}{l}\text { Mean } \pm \text { SE } \\
(\%)\end{array}$ & $\begin{array}{l}\text { Shift } \\
(\%)\end{array}$ & $\begin{array}{l}\text { Mean } \pm \text { SE } \\
(\%)\end{array}$ & $\begin{array}{l}\text { Shift } \\
\begin{array}{c}\text { Mean } \pm \text { SE } \\
(\%)\end{array}(\mathrm{ml})\end{array}$ & $\begin{array}{cc}\text { Shift } & \text { Mean } \pm \text { SE } \\
(\%) & (\%)\end{array}$ & $\begin{array}{l}\text { Shift } \\
(\%)\end{array}$ \\
\hline \multirow{6}{*}{$\mathrm{M}_{2}$} & Cont. & $34.5 \pm 0.68$ & 0.0 & $73.7 \pm 0.35$ & 0.02 & $25.2 \pm 0.15$ & 0.0 & $87.3 \pm 0.88$ & $0.037 .3 \pm 0.87$ & $\begin{array}{ll}0.0 & 10.93 \pm 0.38\end{array}$ & 0.0 \\
\hline & 100 & $33.9 \pm 0.63$ & -1.7 & $76.0 \pm 0.72 *$ & 3. & $24.0 \pm 1.07$ & -4.8 & $90.3 \pm 1.20 * *$ & $3.435 .1 \pm 0.77$ & $-5.910 .83 \pm$ & -0.9 \\
\hline & 200 & $33.4 \pm 0.92$ & -3.2 & $74.2 \pm 0.91$ & 0. & $23.6 \pm 1.14 * *$ & -6.4 & $91.3 \pm 0.67 * *$ & $4.632 .9 \pm 0.99 * *$ & ${ }^{*}-11.810 .60 \pm 0.12$ & -3.0 \\
\hline & 300 & $33.5 \pm 0.98$ & -2.9 & $73.4 \pm 0.26$ & -0.42 & $25.0 \pm 0.85$ & -0.8 & $90.7 \pm 0.67 * *$ & $3.933 .6 \pm 1.38 *$ & $-9.911 .20 \pm 0.27$ & 2.5 \\
\hline & 400 & $33.1 \pm 0.35$ & -4.1 & $74.1 \pm 1.01$ & 0.5 & $25.3 \pm 0.64$ & 0.4 & $91.0 \pm 0.58^{* *}$ & $4.237 .2 \pm 0.38$ & -0.31 & 4.0 \\
\hline & 500 & $34.4 \pm 0.35$ & -0.3 & $72.1 \pm 1.00$ & -2.22 & $26.6 \pm 0.90 * *$ & 5.6 & $92.3 \pm 0.88^{* *}$ & $5.740 .5 \pm 0.67^{*}$ & $8.611 .90 \pm 0.12$ & 8.9 \\
\hline \multirow{6}{*}{$\mathrm{M}_{3}$} & Cont. & $30.8 \pm 0.35$ & 0.0 & $77.8 \pm 0.12$ & 0.03 & $35.2 \pm 0.15$ & 0.0 & $65.0 \pm 1.16$ & $0.038 .3 \pm 0.88$ & $\begin{array}{ll}0.0 & 13.03 \pm 0.03\end{array}$ & 0.0 \\
\hline & 100 & $28.9 \pm 1.01 * *$ & -6.2 & $77.0 \pm 0.22 *$ & -1.03 & $33.8 \pm 0.76^{*}$ & -4.0 & $70.0 \pm 1.16^{* *}$ & $7.736 .0 \pm 0.58^{*}$ & $-6.012 .80 \pm 0.15^{*}$ & -1.8 \\
\hline & 200 & $29.4 \pm 0.63^{*}$ & -4.6 & $75.9 \pm 0.40^{* *}$ & -2.43 & $34.4 \pm 0.68$ & -2.3 & $60.0 \pm 1.16^{* *}$ & $-7.735 .0 \pm 0.58 * *$ & $* \quad-8.612 .93 \pm 0.12$ & -0.8 \\
\hline & 300 & $30.3 \pm 0.82$ & -1.6 & $75.9 \pm 0.47 * *$ & -2.4 & $2 \pm 0.67 * *$ & 8.5 & $60.0 \pm 1.16^{* *}$ & $-7.743 .3 \pm 0.88^{* *}$ & $\pm 0.06^{* *}$ & 5.9 \\
\hline & 400 & $27.5 \pm 0.59 * *$ & -10.7 & $74.9 \pm 0.67 * *$ & -3.73 & $37.7 \pm 0.76^{* *}$ & 7.1 & $70.0 \pm 1.16^{* *}$ & $7.742 .0 \pm 1.16^{* *}$ & * $9.713 .87 \pm 0.12 * *$ & 6.5 \\
\hline & 500 & $29.1 \pm 1.14^{*}$ & -5.5 & $75.5 \pm 0.07 * *$ & -3.03 & $36.5 \pm 0.35^{* *}$ & 3.7 & $60.0 \pm 0.58 * *$ & $-7.747 .3 \pm 0.88 * *$ & * $23.513 .73 \pm 0.09 * *$ & 5.4 \\
\hline \multirow{6}{*}{$\mathrm{M}_{4}$} & Cont. & $44.7 \pm 0.33$ & 0.0 & $80.9 \pm 0.15$ & 0.04 & $44.7 \pm 0.88$ & 0.0 & $60.0 \pm 1.16$ & $0.048 .0 \pm 0.58$ & $0.0 \quad 14.27 \pm 0.22$ & 0.0 \\
\hline & 100 & $43.6 \pm 0.12$ & -2.5 & $83.0 \pm 0.33 * *$ & 2.6 & $44.3 \pm 1.45$ & -0.9 & $63.3 \pm 1.20$ & $5.546 .0 \pm 1.16$ & $-4.214 .23 \pm 0.23$ & -0.3 \\
\hline & 200 & $41.6 \pm 0.53 *$ & -6.9 & $83.3 \pm 0.26^{* *}$ & 3.04 & $1 \pm 1.13$ & 0.9 & $55.0 \pm 0.58 * *$ & $-8.341 .0 \pm 0.58 * *$ & *-14.614.00 \pm 0.17 & -1.9 \\
\hline & 300 & $42.0 \pm 0.20 *$ & -6.0 & $83.5 \pm 0.42 * *$ & 3.24 & $46.8 \pm 0.76^{* *}$ & 4.7 & $50.0 \pm 1.16^{* *}$ & $-16.743 .3 \pm 0.33^{* *}$ & * $-9.814 .23 \pm 0.18$ & -0.3 \\
\hline & 400 & $40.6 \pm 0.46^{* *}$ & -9.2 & $82.2 \pm 0.38 *$ & 1.64 & $44.7 \pm 0.64$ & 0.0 & $65.0 \pm 0.58^{* *}$ & $8.347 .7 \pm 0.88$ & $-0.614 .43 \pm 0.12$ & 1.1 \\
\hline & 500 & $44.8 \pm 0.83$ & 0.2 & $81.6 \pm 0.56$ & 0.94 & $46.9 \pm 0.21 * *$ & 4.9 & $50.0 \pm 0.58^{* *}$ & $-16.748 .3 \pm 0.88$ & $0.6 \quad 14.73 \pm 0.09$ & 3.2 \\
\hline
\end{tabular}

SE: Standard error, Cont.: Control, ${ }^{*}$ and $* *$ statistically significant differences from control at $5 \%$ and $1 \%$.

Regarding the $\mathrm{M}_{4}$ mutated population of Kate A-I variety, significant positive shifts in quantitative mean performance were observed for TW with values of 3.2, 3.0, 2.6, and 1.6\% $(300,200$, 100 , and $100 \mathrm{~Gy}$ ), WGC at values of 4.9 and $4.7 \%$ (500 and $300 \mathrm{~Gy}$ ) and GI at the value of $8.3 \%$ (400 Gy). However, gradually significant decreases were calculated in the mutant populations for TGW in 400, 200, and $300 \mathrm{~Gy}$, GI in 500, 300, 400, and $200 \mathrm{~Gy}$, and ZSV in 200 and $300 \mathrm{~Gy}$, compared to controls in the $\mathrm{M}_{4}$ generation.

TGW and TW are the measures of grain density in kg per hectoliter. It is useful for the grading of wheat. These are because test weight is related to grain density rather than weight and the denser kernels tend to contain more endosperm (flour) (Williams et al., 1986). The present study observed the negative effects on an average weight of grains in nearly all the cases of gamma rays doses of bread wheat genotypes except IBWSN4 advanced line in $\mathrm{M}_{2}$ mutated populations where the grain weight showed some increment over the control. Despite the increase in radiation intensity, asynchronous decreases in average values for the feature were observed for the mutated population of wheat genotypes in all generations. The maximum decrease in the average values of grain weight was observed at 400 Gy of radiation dose (13.1) concerning control for the $\mathrm{M}_{3}$ population of the IBWSN4 line (Table 3). In general, most of the radiation doses showed adverse effects on grain weight. In the case of TW, it can be said that the same trend is valid for it. The present results are in agreement with the findings of Salem et al. (2016), who explained that physical properties such as 1000 grain weight and test weight were not affected by increasing gamma doses up to $3.5 \mathrm{kGy}$. However, Ainmasaun et al. (2014) observed an increase in the average 100-grain weight at $80 \mathrm{GY}$ of radiation dose as it was found at $15 \mathrm{kR}$ radiation dose in the study. Such type of contradiction might be due to either difference in genetic material under study or due to agro-climatic variations under which the experiment was carried out.

The findings on WGC showed that significant positive shifts in quantitative mean performance were the highest in all of the mutated populations of IBWSN4 advanced lines than those of Kate A-I and Bezostaja 1 varieties compared to controls, indicating enhanced scope for selection. In other words, the most sensitive genotype to gamma irradiation was IBWSN4, while the most resistant genotype was Bezostaja 1. This result may be indicated that the sensitivity to gamma irradiation depends on the genotype. Besides, the same gamma-ray doses will produce opposite changes in the physical properties 
of the gluten depending upon the moisture content of the irradiated grain (Sosedov and Vakar, 1961). The gluten of a grain with a moisture content of $13.4 \%$ became increasingly weak, its specific extensibility increased, its elasticity diminished, and the wet and dry gluten contents decreased with increasing radiation dosage. In general, the mean values for WGC in all mutated populations of 3 bread wheat genotypes did not alter significantly despite the increased variance observed for these characters, suggesting the incidence of plus and minus mutations with equal frequency (Oka et al., 1958). The present results are in agreement with the findings of Ibrahim (2008), who stated the relative increase in wet gluten depending on cultivar.

In the case of GI, there was a significant gradual increase for Bezostaja 1 and Kate A-I varieties at $\mathrm{M}_{4}$ and at $\mathrm{M}_{2}$ populations respectively, while all mutated populations of IBWSN4 were negative compared to controls. In general, the mean value of irradiated populations remains unchanged, possibly due to the symmetrical occurrence of mutations with plus and minus genotypic effects (Oka et al., 1958). These findings are similar to the results of Anwar et al. (2015) who indicated that $\gamma$-irradiation increased in quality of gluten through gluten index from $71.22 \%$ to $79.31 \%, 85.11$ and $93.21 \%$ for the irradiated sample at 3, 6 and $9 \mathrm{kGy}$ respectively. Ibrahim (2008) stated that the increase in mutation doses caused decreases in gluten index values.

Regarding ZSV, the significant range was the greater positive direction in the $\mathrm{M}_{2}$ and $\mathrm{M}_{4}$ mutant populations of Bezostaja 1 and IBWSN4 and in the $\mathrm{M}_{3}$ mutant populations of Kate A-I, compared to controls. These results are confirmed by the finding of Rahemi et al. (2018) and Dolińska et al. (2001), who explained that Zeleny sedimentation values increased significantly in mutated populations as compared with the control. Mansour et al. (2012) explained that increases or decreases in sedimentation values in $\mathrm{M}_{2}$ populations compared to control might differ depending on the genotype of bread wheat.

In the present study, a significant shift in quantitative mean performance was positive for $\mathrm{PC}$ in $\mathrm{M}_{3}$, and $\mathrm{M}_{4}$ populations of IBWSN4 and $\mathrm{M}_{3}$ population of Kate A-I were also due to the effect of gamma rays while remaining unchanged. Similar results were reported by Swaminathan (1972), Swaminathan (2001), Borzouei et al. (2013), Rahemi et al. (2018). On the other hand, the mean value of irradiated populations of Bezostaja 1 remains unchanged due to its high protein content because the high content of proteins acts as a protective mechanism to fight the harmful effects of gamma radiation (Al-Rumaih and Al-Rumaih, 2008).

\section{Conclusion}

The increases or decreases in mean performance compared to control were irregular for the values related to the quality characteristics examined in mutant generations. When assessed together in the $\mathrm{M}_{2}, \mathrm{M}_{3}$, and $\mathrm{M}_{4}$ generations, the responses of bread wheat genotypes to different mutagen applications differ. The Bezostoja 1 was less affected than the gamma irradiation, while the IBWSN 4 genotype showed higher sensibility. This suggested that mutagen treatment was associated with the genetic base of the genotypes. It can be generally said that although the shifts per see from the controls for ZSV, GC, and PC were significant, while TGW, GI, and TW showed an unchanged or slightly negative response in the $\mathrm{M}_{2}, \mathrm{M}_{3}$, and $\mathrm{M}_{4}$ generations. This also indicates that it may be more appropriate to perform selection after $\mathrm{M}_{4}$ generation for seed quality traits in mutant populations. Although the effect of mutagen doses varies depending on the character, genotype, and mutant generation, it can be said that the most appropriate gamma-ray doses were 300 and 200 Gy doses because of causing significant shifts per see from the controls.

\section{Acknowledgements}

The above analysis of grain quality was carried out using multi-year data obtained in the process of evaluating early mutant population trials for performance in rainfed conditions. No special genetic parameters or other grain yield measurements were made. From these, the authors were able to obtain a very useful understanding of some of the reasons why grain yield and yield components (Balkan et al., 2019) and seed quality traits (this paper) were affected by gamma irradiation and genetic variability. Together with the results of Balkan (2018) and Balkan et al. (2019), the knowledge obtained through this paper will be helpful for the breeders while making a selection for yield and quality of potentially improved wheat mutant germplasm. 


\section{References}

AACC. (2000). Approved methods of the American Association of cereal chemists. Methods 38-12 and 46-13, tenth ed. American Association of Cereal Chemists, St. Paul, MN.

Ahloowalia, B.S., Maluszynski, M. \& Nichterlein, K. (2004). Global impact of mutation-derived varieties. Euphytica 135, 187-204.

Ahmadi-Gavligi, H., Sahari, M.A., Azizi-Tabrizzad, M.H. \& Rashmeh-Karim, K. (2004). Protein content of important wheat varieties in Iran and their technological properties. International Journal of Environmental Science and Technology 1(2), 1-7.

Al-Rumaih, M. M. \& Al-Rumaih, M.M. (2008). Influence of ionizing radiation on antioxidant enzymes in three species of Trigonella. American Journal of Environmental Science 4(2), 151-156.

Animasaun, D.A., Morakinyo, J.A. \& Mustapha, O.T. (2014). Assessment of the effects of gamma irradiation on the growth and yield of Digitaria exilis (Haller). Journal of Applied Biosciences 75, 6164-6172.

Anwar, M.M., Asael, M.A. \& El-Adly, N.A. (2015). Gamma radiation influence on rheological and technological characteristics of wheat flour (misr-1) and sensory properties of pan bread. Journal of Nuclear Technology and Applied Science 3(2), 89-97.

Balkan, A., Bilgin, O., Başer, İ., Göçmen, D.B., Demirkan, A.K. \& Deviren, B. (2019). Improvement of grain yield and yield associated traits in bread wheat (Triticum aestivum L.) genotypes through mutation breeding using gamma irradiation. Journal of Tekirdag Agricultural Faculty $16(1), 103-111$.

Balkan, A. (2018). Genetic variability, heritability and genetic advance for yield and quality traits in M2-4 generations of bread wheat (Triticum aestivum L.) genotypes. Turkish Journal Field Crops 23(2), 173-179.

Borzouei, A., Kafi, M., Sayahi, R., Rabiei, E. \& Amin, P.S. (2013). Biochemical response of two wheat cultivars (Triticum aestivum L.) to gamma radiation. Pakistan Journal of Botany 45(2), 473477.

Brankovic, G., Dodig, D., Pajic, V., Kandic, V., Knezevic, D., Duric, N. \& Zivanovic, T. (2018). Genetic parameters of Triticum aestivum and Triticum durum for technological quality properties in Serbia. Zemdirbyste-Agriculture 105(1), 39-48.

Brunner, H. (1991). Methods of induction of mutations. In: Mandal, A. K., Ganguli, P. K., Banerjee, S.P. (Eds.), Advances in Plant Breeding. CBS Publishers and Distributors, Delhi.

Byerlee, D. \& Moya, P. (1993). Impact of International Wheat Breeding Research in The Developing World. pp. 12-16. In: Klatt, A.R. (Eds.). Wheat production prospects: past, present and future, CIMMYT, Mexico.

Dolińska, R., Klockiewicz-Kamińska, E., Zabielski, J. \& Warchalewski, J.R. (2001). The technological characteristics of the first generation of wheat grain which was gamma irradiated before sowing. Żywność 4(29), 23-35.

Gralik, J. \& Warchalewski, J.R. (2006). The influence of $\gamma$-irradiation on some biological activities and electrophoresis patterns of wheat grain albumin fraction. Food Chemistry 99, 289-298.

Ibrahim, E.I.E. (2008). Influence of gamma-irradiation on the physico-chemical properties of the two Sudanese wheat (Triticum aestivum) cultivars. M.Sc Dissertation, University of Khartoum, Faculty of Agriculture.

ICC. (1972). ICC Standart Method 166/1: Determination of the sedimentation value (according to Zeleny) as an Approximate Measure of Baking Quality.

ICC. (1994). ICC Standard No 155: Determination of wet gluten quantity and quality (Gluten Index ac. To Perten) of Whole Wheat Meal and Wheat Flour.

ICC. (1995). ICC Standard No 159: Determination of protein by near-infrared reflectance (NIR) Spectroscopy.

Jain, S.M. (2005). Major mutation-assisted plant breeding programmes supported by FAO/IAEA. Plant Cell Tissue Organa Culture 82, 113-121.

Kharkwal, M.C. \& Shu, Q.Y. (2009). The Role of induced mutations in world food security. In: Induced Plant Mutations in the Genomics Era, Proceedings of the International Joint FAO/IAEA Symposium IAEA, Vienna. 
MacKay, T.F.C. (2011). Mutations and quantitative genetic variation: lessons from Drosophila. Philosophical Transactions of the Royal Society B 365, 1229-1239.

Mansour, H.M., Abdel-Tawab, F.M., Fahmy, E.M., Mahrous, S.R., Eissa, H.F. \& Saleh, O.M. (2012). Modifications of gene expression of some quality traits in bread wheat using gamma irradiation. Egyptian Journal of Genetics and Cytology 41, 37-48.

Marathe, S.A., Machaiah, J.P., Rao, B.Y.K., Pednekar, M.D. \& Rao, V.S. (2002). Extension of self-life of whole flour by gamma radiation. International Journal of Food Science and Technology 37, 163-168.

Mba, C. (2013). Induced mutations unleash the potentials of plant genetic resources for food and agriculture. Agronomy 3, 200-231.

Mba, C., Afza, R., Bado, S., Jain, S.M., Davey, M.R. \& Anthony, P. (2010). Induced mutagenesis in plants using physical and chemical agents. Plant Cell Culture: Essential Methods 111-130.

Nayeem, K.A., Devkule, S.N. \& Bhagwat, S.G. (1999). Seed protein variations in radiation induced mutant of wheat. Indian Journal of Genetics and Plant Breeding 59, 363-369.

Oka, H.I., Hayashi, J. \& Shiojlri, I. (1958). Induced mutations of polygenes for quantitative characters in rice. Journal of Heredity 49, 11-14.

Paredes-Lopez, O. \& Covarrusbias-Alvarez, M.M. (1984). Influence of gamma radiation on the technological and functional properties of bread wheats. Journal of Food Technology 19, 225231.

Rahemi, M.R., Yamchi, A., Navabpour, S., Soltanloo, H. \& Roepstorff, P. (2018). Gamma ray effects on traits related to wheat bakery quality in Roshan cultivar. Journal of Crop Breeding 10(26), $120-127$.

Salem, E.A., Soliman, S.A., El-Karamany, A.M. \& Abd El-Shafea, Y.M. (2016). Effect of utilization of gamma radiation treatment and storage on total fungal count, chemical composition and technological properties wheat grain. Egyptian Journal of Biological Pest Control 26(1), 163 171.

Seabourn, B.W., Tilley, X., Herald, Z.S.M. \& Park, S.H. (2012). A rapid, small-scale sedimentation method to predict breadmaking quality of hard winter wheat. Crop Science 52,1306-1315.

Sosedov, N.I. \&Vakar, A.B. (1961). Effect of x-rays on the biochemical properties of wheat, Proceedings 5th International Congress Biochemistry. Moscow, August 10-16, p. 133.

Steel, R.G.D. \& Torrie, J.H. (1980). Principle and procedures of statistics: A biometrical approach. McGraw Hill Book Co. Inc. New York.

Suprasanna, P., Mirajkar, S.J. \& Bhagwat, S.G. (2015). Induced mutations and crop improvement. In: Bahadur, B., V. M. Rajam, L. Sahijram and K. V. Krishnamurthy (Eds.), Plant biology and biotechnology. Vol. I. Plant Diversity, Organization, Function and Improvement, Springer India

Swaminathan, M.S. (1972). Mutational reconstruction of crop ideotypes. Induced mutations and plant improvement. In: Proc Study Group Meeting of IAEA-FAO, Buenos Aires 1970.1AEA, Vienna. 